Prouska, R. and Psychogios, A. (forthcoming). Should I say something? A framework for understanding silence from a line manager's

perspective during an economic crisis. Economic and Industrial Democracy.

\title{
Should I say something? A framework for understanding silence from a line manager's perspective during an economic crisis
}

\begin{abstract}
The impact of the recent economic crisis on firms' key employment priorities has been widely discussed in the literature. Although research has focused on how employee silence is manifested in times of economic crisis, less is known about how line managers experience voice and silence from their own perspective and organizational position. Line managers are an intriguing group to study because they act as both supervisors to their teams and as supervisees (employees) to senior managers/business owners. We draw on qualitative data gathered from line managers in 35 small non-unionized enterprises in Greece in two periods of time (2012 and 2014) during the economic crisis. We develop a framework for understanding line manager's experience of silence in such contexts and, within this framework propose 'cynical silence' as a new type of silence relevant to an economic crisis context.
\end{abstract}

\section{Keywords}

Employee silence, cynical silence, economic crisis, line managers, small enterprises, Greece 
Prouska, R. and Psychogios, A. (forthcoming). Should I say something? A framework for understanding silence from a line manager's perspective during an economic crisis. Economic and Industrial Democracy.

\section{Introduction}

The global economic crisis has greatly impacted on firms' key employment priorities. Firms responded to recession by downsizing, restructuring work, changing working time arrangements, and by implementing pay freezes or reducing pay and rewards. These effects have been more prominent in countries significantly hit by the crisis, such as those in the South European periphery (Psychogios et al., 2017; Prouska et al., 2016; Teague and Roche, 2013). The above practices or responses have had a negative impact on employees' quality of working life (Chatrakul Na Ayudhya et al., 2017), psychological contract (Conway et al., 2014) and health and well-being (Kondilis et al., 2013). This has prompted more research on the impact the crisis has had on employee voice as a key employment issue and priority (Kranz and Steger, 2013; Prouska and Psychogios, 2016).

In general, 'voice' refers to how employees are able to have their say regarding work activities and decision-making issues within the organization in which they work, although it is often used interchangeably with concepts such as participation, engagement, involvement and empowerment (Wilkinson and Fay, 2011). Voice has been found to lead to employee motivation, satisfaction, engagement and commitment, and supporting organizational decision-making (Beer and Eisenstat, 2000; Morrison and Milliken, 2000; Tangirala and Ramanujam, 2008). Studying the absence of voice within an economic crisis context, particularly within small enterprises, is important because it can lead to negative effects for employees, such as reduced employee engagement, involvement and participation, at a time when organizations need a committed workforce (Schlosser and Zolin, 2012).

Given that we examine small non-unionized enterprises, we frame this paper within an HRM perspective of voice, because the traditional Industrial Relations (IR) or Employee Relations (ER) perspective focuses on indirect voice, such as collective representation through trade unions (Barry and Wilkinson 2016). The HRM perspective assumes that 
Prouska, R. and Psychogios, A. (forthcoming). Should I say something? A framework for understanding silence from a line manager's perspective during an economic crisis. Economic and Industrial Democracy.

'setting up employee voice mechanisms potentially allows staff to influence events at work, but having a voice does not mean it is listened to' (Barry and Wilkinson, 2016: 265). This approach focuses on direct voice schemes and on the role of management in creating voice mechanisms. However, because the context of our study (the Greek economic crisis) has created adverse working conditions in small enterprises (Psychogios et al., 2017) with implications for the structure of work, working time arrangements and pay, we include in our approach avenues for employees to express grievance, dissatisfaction or concerns to management, aimed at benefiting the employee by resolving critical employment issues.

Within the context of the macro-economic context of the recent global economic crisis and, specifically, within the Greek context which is characterized by weak institutional foundations in terms of employment policies, employment protection, industrial relations and social protection, we adopt Milliken's et al. (2003) definition of employee silence. This definition, in its broader sense, refers to silence as the employee's reluctance to speak up about organizational issues. In this paper, we focus on working conditions issues affecting employees. This reluctance to speak up may be caused by the employee's conscious choice, or by management structures, which organize employees out of the voice process (Donaghey et al., 2011).

Research has so far looked at the employers' and employees' perspective on silence (Prouska and Psychogios, 2016; Willman et al., 2006) and the leaders' role in promoting or inhibiting voice at work (Detert and Trevino, 2010; Kranz and Steger, 2013; Morrison, 2014; $\mathrm{Xu}$ et al., 2015). Although some research has focused on exploring silence within the context of the recent economic crisis (Kranz and Steger, 2013; Prouska and Psychogios, 2016; Schlosser and Zolin, 2012), there is still a significant gap in our understanding of how it is manifested in small businesses. 
Prouska, R. and Psychogios, A. (forthcoming). Should I say something? A framework for understanding silence from a line manager's perspective during an economic crisis. Economic and Industrial Democracy.

The rationale for focusing on small enterprises within the Greek context is twofold: Firstly, voice, and consequently silence, in small enterprises is under-theorized and underresearched (Gilman et al., 2015). What we do know so far is that small businesses are lacking formal employee representation structures (Bae et al., 2011) and formal management practices (Behrends, 2007; Psychogios et al., 2016; Wilkinson, 1999). They do not have developed HRM departments and HR practices are usually devolved to line managers (Kotey and Slade, 2005). This informality in HRM has been linked to resource constraints, including internal HR expertise and familial/paternalistic organizational cultures (Gilman et al., 2015). Where HRM voice initiatives are implemented, they mimic those initiatives found in larger organizations on the basis of the assumption that they will lead to enhanced employee commitment (Wilkinson et al., 2007).

Small businesses are mostly non-unionized, but may incorporate more direct and informal voice channels between employer and employees (Marlow and Gray, 2005). The level of formalization depends on a variety of internal and external factors (Sameer and Ozbilgin, 2014). On the one hand, employees in small enterprises are seen as rather quiescent, not engaging in overt conflict with management (Wilkinson et al., 2007). On the other hand, managers engage more in information than consultation as they see the latter as a threat to management control (Dundon and Gollan, 2007). In addition, small enterprises are less likely to have formally approved information and consultation agreements (Wilkinson et al., 2007). In such organizational contexts, therefore, how possible is it for employee voice to be heard?

Secondly, the impact of the Greek crisis on small businesses has been severe with negative implications for working conditions. The crisis has exacerbated the problem of access to finance for small enterprises (Psillaki and Eleftheriou, 2015). This led to increased payment delays on receivables which resulted in shortage of working capital, a decrease in liquidity, and an increase in defaults, insolvencies and bankruptcies (OECD, 2009). As a 
Prouska, R. and Psychogios, A. (forthcoming). Should I say something? A framework for understanding silence from a line manager's perspective during an economic crisis. Economic and Industrial Democracy.

response, small businesses engaged in cost-cutting as a remedy to restore profitability and adjusted production to lower demand levels (all of which lead to a reduced wage bill through lay-offs, subsequently impacting labor markets). They further searched for additional sources of liquidity (e.g. extending own payment delays), and postponing investment and expansion plans (OECD, 2009). The severe reduction of external credit during the crisis, therefore, has been of relevance to Greek small enterprises. In addition, there is a clear link between external financing obstacles and adverse working conditions (Psychogios et al., 2017). The crisis has caused labor market deregulation and, thus, affected the extent to which employees can 'be heard' about issues that concern them at work (Wood et al., 2015), therefore making this an important topic to study within such enterprises.

In this respect, this paper explores employee silence from a line-management perspective in small enterprises operating in a long-term economic crisis context. We use the context of Greek small businesses to explore how line managers experience voice and silence from their own perspective and organizational position. We break this aim down into two research questions: 1) What is the role of line managers in promoting or inhibiting voice within the teams they manage during an economic crisis? 2) How do line managers perceive the impact of the economic crisis on their ability to express dissatisfaction, complaint or concern to senior managers/owners?

The paper contributes to employee silence theory by presenting a framework for understanding line manager's experience of silence in such contexts. It specifically contributes to the special issue of Economic and Industrial Democracy on 'Global Economic Crisis, Work and Employment' in two ways: firstly, by exploring the implications of economic crisis on employee voice as a key employment priority and, secondly, by investigating these implications from a line management perspective. The next three sections provide an overview of employee silence, explore the role of line managers in voice/silence 
Prouska, R. and Psychogios, A. (forthcoming). Should I say something? A framework for understanding silence from a line manager's perspective during an economic crisis. Economic and Industrial Democracy.

in small companies, and provide the background to the Greek economic crisis focusing on its impact on employee voice.

\section{Employee silence: A brief overview}

Employee silence has been categorized in various typologies (for a comprehensive overview see Brinsfield, 2014). Various causal effects of employee silence have been explored in the literature: (i) silence caused by social pressure for conformity (pluralistic ignorance, diffusion of responsibility, groupthink, spiral of silence, Abilene paradox) (Allport, 1924; Bowen and Blackmon, 2003; Harvey, 1974; Henriksen and Dayton, 2006; Janis, 1972; Latane and Darley, 1968; Lepine and Van Dyne, 1998; Noelle-Neumann, 1974); (ii) silence caused by feelings of hope that the situation will soon improve (loyalty) (Hirschman, 1970); (iii) silence caused by a reluctance to hear or be the conveyer of bad news (mum effect, dead ear syndrome or deaf effect) (Conlee and Tesser, 1973; Cuellar et al., 2006; Peirce et al., 1998; Rosen and Tesser, 1971); (iv) silence caused by a willingness to be a good organizational citizen (sportsmanship, prosocial silence, cooperative silence) (Organ, 1988; Van Dyne et al., 2003; Wang et al., 2012); (v) silence caused by fear (individual and organizational) (climate of silence, organizational silence defensive silence, quiescence silence, diffident silence, relational silence) (Brinsfield, 2013; Detert and Edmondson, 2011; Milliken et al., 2003; Morrison and Milliken, 2000; Pinder and Harlos, 2001; Van Dyne et al., 2003); (vi) silence caused by a belief that voice is futile (ineffectual change) (Brinsfield, 2013; Morrison and Milliken, 2000; Pinder and Harlos, 2001; Van Dyne et al., 2003); (vii) silence caused by acceptance of a situation (acquiescence silence, disengaged silence) (Brinsfield, 2013; Pinder and Harlos, 2001; Van Dyne et al., 2003); and (viii) silence caused by deviant behavior (deviant silence) (Brisnfield, 2013; Gruys and Sackett, 2003). 
Prouska, R. and Psychogios, A. (forthcoming). Should I say something? A framework for understanding silence from a line manager's perspective during an economic crisis. Economic and Industrial Democracy.

More recently, research has focused on identifying types of silence present in small enterprises operating under economic crisis conditions (Prouska and Psychogios, 2016). Employees are discouraged from expressing their own opinions and dissatisfaction (Schlosser and Zolin, 2012), because voice seems risky, or as a waste of time and effort (Morrison, 2014). This perception of risk occurs because economic crisis is associated with increased unemployment and job insecurity (Chung and Van Oorschot, 2011), pay cuts, restructuring, downsizing and layoffs (Russell and McGinnity, 2014). These risks make employees less likely to speak up (Ng and Feldman, 2011) because of their own implicit beliefs about the futility or danger of speaking up (Prouska and Psychogios, 2016). Employees assume that speaking up in certain instances of work situations will lead to negative consequences. The employee silence typologies relevant to an economic crisis context have been presented by Prouska and Psychogios (2016). They argue that economic crisis brings silence at work due to a fear of the consequences of speaking up (e.g. defensive silence, relational silence, climate of silence), due to a response to the perceived duration of the crisis (e.g. sportsmanship, cooperative silence, ineffectual silence, acquiescence silence, disengaged silence), and due to silence being the norm (social empathy silence, climate of fear, habituated silence). An overview of these silence typologies relevant to an economic crisis context is provided in Table 1 below.

--Insert Table 1 about here--

\section{The role of line managers in voice/silence in small companies}

Line managers, strictly speaking, are people in management directly responsible for production or services, but not responsible for service functions such as marketing, finance and HR (Brewster et al., 2015). In this paper, and given that we study small enterprises, we 
Prouska, R. and Psychogios, A. (forthcoming). Should I say something? A framework for understanding silence from a line manager's perspective during an economic crisis. Economic and Industrial Democracy.

adopt a broader definition of line managers: for the purpose of this study we mean any manager who has supervisory responsibilities for a team within their function; this may include managers responsible for production or services and managers responsible for service functions including HRM. Line managers in small enterprises play multiple roles. They are responsible for team coordination, function management, monitoring employees' performance, as well as communicating top management and employers' decision to their teams. These are roles typically undertaken by middle managers in medium and large companies (Psychogios et al., 2008).

Small workplaces are mostly characterized by informal employee voice practices (Bae et al., 2011, Behrends, 2007; Kotey and Slade, 2005; Psychogios et al., 2016; Wilkinson, 1999). Informal voice has been defined as 'the day to day relations between supervisors and subordinates in which the latter are allowed substantial input into decisions [...] a process which allows workers to exert some influence over their work and the condition under which they work' (Strauss, 1998, p. 15). Line managers have a critical role in people management by interacting with employees on a day-to-day basis (Gilbert et al., 2011) and, therefore, have a key role in facilitating informal voice at work (Dundon et al., 2005). Immediate supervisors do not just reinforce an overall climate for speaking up set by leaders at the top, but they influence subordinates' voice perceptions by effectively or ineffectively serving as intermediaries between their subordinates and senior leaders (Detert and Trevino, 2010). This means that line managers play a dual role in facilitating voice at work: Firstly, they act as the first point of contact for employees within their teams allowing for the raising of issues that concern them. Secondly, they act as intermediaries between their subordinates and senior managers.

Key factors crucial to the success of informal voice practices include line managers' approachability and receptivity (Landau, 2009), conditions which have been found to affect 
Prouska, R. and Psychogios, A. (forthcoming). Should I say something? A framework for understanding silence from a line manager's perspective during an economic crisis. Economic and Industrial Democracy.

the extent employees feel they can bring their concerns to their supervisors without being penalized (Saunders et al., 1992). These line manager traits can be more important than the number of voice mechanisms present in a workplace or the employees' propensity to speak up. For example, Detert and Trevino (2010) found that immediate supervisors' personal characteristics can strongly influence corresponding employee voice perceptions (e.g. open or empathetic supervisor vs. closed or abusive supervisor).

The idea that line managers can successfully enable informal voice practices through their personal traits assumes that they move away from having a directive role towards a supportive role and for this they would need to acquire new skills (Wilkinson et al., 1993). The assumption here is that line managers believe in the principles underlying voice, see the value of voice and feel secure about their own futures in organizations, all of which may not be true (Denham et al., 1997; Wilkinson et al., 2004). Line managers also consider hard approaches to managing teams as more effective than employee involvement approaches (Wilkinson et al., 1993). In addition, although line managers may see the value of voice, they are conflicted with pressing production or service goals, which are emphasized and rewarded by senior management at the expense of voice goals (Fenton-O'Creevy, 2001). Further to this, posts held by line managers are the ones likely to alter most in periods of change, while at the same time line managers themselves are called to play a critical change agent role in engaging employees (Wilkinson et al., 2012). This makes line managers feel disbelief and uncertainty over the value that senior managers place on employee involvement. Therefore, line managers' role in voice may be restricted if we accept that the decision to voice is not a free one, but it can be conditioned by management's agendas and institutional structures (Barry and Wilkinson, 2016). This means that they may be part of such senior management agendas to purposefully control voice, but they may also be unwillingly disempowered by such agendas from acting as voice intermediaries or catalysts. 
Prouska, R. and Psychogios, A. (forthcoming). Should I say something? A framework for understanding silence from a line manager's perspective during an economic crisis. Economic and Industrial Democracy.

Despite the importance of voice in smaller settings, there is limited research exploring how informal voice takes place, particularly through line managers, in different contexts (Gilman et al., 2015; Marchington and Suter, 2013). Our research addresses this gap by looking at how line managers experience voice and silence from their own perspective and organizational position in an economically turbulent setting: Greece. The next section provides more information on the particular context of the study.

\section{The impact of the Greek economic crisis on employee voice}

Although research has focused on the impact of crisis on human resource management (HRM) and working conditions, there is lack of research on institutionally weak countries (Psychogios et al., 2016) and their response to the crisis in terms of employee silence. This makes the Greek context an interesting case. The Greek economy remains in deep recession since 2009 with no visible signs of a recovery soon (Kosmidou et al., 2015) with some arguing for what is seen as the institutionalization of crisis in Greece (O'Reilly et al., 2011). Greek institutions have been traditionally weak (Prouska and Kapsali, 2011) but have become even more dysfunctional since the crisis in terms of regulating labor markets and securing viable and sustainable growth (Kornelakis and Voskeristian, 2014).

The Greek crisis has particularly affected smaller businesses (OECD, 2016) which form the majority of Greek enterprises (Prouska and Kapsali, 2011). Small enterprises had to overcome increased taxation and the banks' reluctance to provide them with lines of credit to support them financially, which led to many of them facing liquidity problems (Kouretas and Vlamis, 2010). In June 2015, the implementation of capital controls intensified this problem (Samitas and Polyzos, 2016). Employee dissatisfaction was particularly high (Arghyrou and 
Prouska, R. and Psychogios, A. (forthcoming). Should I say something? A framework for understanding silence from a line manager's perspective during an economic crisis. Economic and Industrial Democracy.

Tsoukalas, 2010) due to the increased layoffs, decreased salaries, and overall work intensification.

Since 2011, there has been a rapid decentralization of collective bargaining to the enterprise level caused by the crisis, and a decrease in the number of labor market regulations deriving from sector-level and occupational collective employment agreements (Ioannou and Papadimitriou, 2013). This means that a large number of Greek small enterprises are not covered by collective bargaining agreements (Featherstone, 2008). There is also a minimum of 21 employees required for a union to be established (Kouzis, 2000) and this limitation does not enable smaller companies to organize a union at work. The Greek law also provides for work council structures, but these are only found in a few companies (ETUI, 2016). It also provides for 'associations of persons' to exist; associations operating without a time limitation and with the authority to sign collective agreements for companies of any size (ETUI, 2016).

But how has the Greek economic crisis affected employees in terms of issues they are reluctant to raise to management? There is very limited research on this. A recent study on employee silence in small Greek enterprises was conducted by Prouska and Psychogios (2016) arguing that the main types of issues employees would not speak up about were relating to reductions in salary (unpaid work, unpaid overtime work), reductions in benefits (paid leave), increase in working hours and worsening working conditions (lack of infrastructure or resources). The authors developed a framework for understanding the evolution of silence over time during crisis and proposed silence typologies relevant to an economic crisis period (see Table 1). Beyond the limited research cited above, there is no empirical evidence of the forms of silence within smaller enterprises in a crisis environment. 
Prouska, R. and Psychogios, A. (forthcoming). Should I say something? A framework for understanding silence from a line manager's perspective during an economic crisis. Economic and Industrial Democracy.

\section{Research Methods}

We adopted an interpretivist approach to study human actions, motives, feelings and experiences from the perspective of line managers (Bryman and Bell, 2003). We build on other qualitative studies on the dynamics at work (Gersick et al., 2000; Milliken et al., 2003; Prouska and Psychogios, 2016) to explore line managers' perceptions of workplace voice during the crisis period. We used an exploratory qualitative research design, collecting data through semi-structured interviews because we wanted to explore participants' perceptions and probe for more information and clarification (Wengraf, 2001).

We conducted interviews in two different time phases with line managers working in 35 small enterprises. The line managers were holding various positions and professional specializations in their organizations. The rationale was to have participants from the first line of supervision that were aware of employee issues and the demands and challenges that crisis brought to their companies. Most of them were individuals with posts between line employees and top-management (often owners). Their organizational position created a threefold pressure; top-down: they had to adjust to decisions and pressures from the top; bottomup: they had to accommodate employees' needs and voice; and finally, they had their own voice on issues associated with their position in the company. Although, this group of managers can sometimes be considered as middle managers (Floyd and Wooldridge, 2000), we have preferred to refer to them as 'line managers' in order to show their direct relation with their teams, given the concertation of power at the top in small enterprises (Trow, 1961). In this respect, the participants were responsible for first line supervision either within their specialized functions (e.g. HR, Logistics, Accounting, etc.) or they were team leaders responsible for products and services. Finally, in all cases, our participants did not have critical influence over formulating new strategies in their organizations (indicative of their 
Prouska, R. and Psychogios, A. (forthcoming). Should I say something? A framework for understanding silence from a line manager's perspective during an economic crisis. Economic and Industrial Democracy.

voice levels). This was happening even in the case of HR managers who had a limited role performing functional HR activities (e.g. payroll, training) rather than contributing to $\mathrm{HR}$ planning and strategy.

The enterprises were operating in three main industries: manufacturing ( 5 businesses), retail (12 businesses) and services (including professional services) (18 businesses). The sample of companies was obtained from the researchers' professional network using six criteria in selection. Firstly, we targeted companies from the main three industries (manufacturing, retail, services). The rationale was to explore possible differences between them. Most companies belonged to the service industry and this reflects the importance of this industry for the Greek economy (almost 83\% of the GDP; Eurostat, 2017). A significant number of them were operating in the retail industry, which is the second most important industry in Greece dominated by small businesses (OECD, 2016). The second criterion was the specific sector within which businesses were operating. Here we attempted to capture a wide range of sectors in order to enable us to make comparisons. The third criterion was organizational size. All companies in our sample are classified as small since they employ fewer than 50 employees, a size quite typical for Greek enterprises (Psychogios and Wood, 2010). The fourth criterion was related to a lack of formal voice in the form of a trade union. None of the selected companies had a trade union in place because we wanted to study informal forms of voice and/or silence in these enterprises. The fifth criterion was the city of operation. Here we selected from the two main Greek urban centers (Athens and Thessaloniki). Finally, the sixth criterion of selection was to include companies with at least ten years of operation because we wanted to ensure that they were operating for a period of time prior to the crisis. Table 2 provides an overview of the companies that participated in the study and the position of the interviewees. 
Prouska, R. and Psychogios, A. (forthcoming). Should I say something? A framework for understanding silence from a line manager's perspective during an economic crisis. Economic and Industrial Democracy.

--Insert Table 2 about here--

\section{Data collection and interview protocol}

Each participant was interviewed twice in two interview phases: Phase I SeptemberDecember 2012 and Phase II May-July 2014. In 7 businesses, the line managers had left the organization or the business itself had closed down by Phase II (another critical consequence of the long-term crisis). In these cases, we did not conduct interviews with these organizations in Phase II (hence our sample consisted of 28 companies in Phase II).

The interviews lasted 45 minutes to 1 hour. The interviews were conducted in the Greek language as this was the participants' mother tongue. Therefore, the interview questions were written in English, translated into Greek, piloted, reviewed and revised and then used in the main stage of data collection. All interviews were tape-recorded, subsequent to permission, and then transcribed and translated back into the English language.

Each interview started with a brief description of the study. Participants were assured that any information they provided would remain anonymous and confidential. They were also informed of their right to withdraw from the study at any point of the research. The interview questions were organized in four sections. The first section asked for the participants' demographic data, capturing information on age, gender, position in the organization, length of service in current organization, and number of staff they line managed. The second section asked participants to reflect on their experience of how the economic crisis had affected the daily management of staff. The focus was on uncovering their own perceptions of how the economic crisis had affected the organizational environment within which they operated and their role as line managers. The third section asked participants to reflect on how they experienced the impact of the economic crisis on the way 
Prouska, R. and Psychogios, A. (forthcoming). Should I say something? A framework for understanding silence from a line manager's perspective during an economic crisis. Economic and Industrial Democracy.

they communicated everyday work issues to staff and enabled subordinates to communicate with them. The focus was on exploring the way in which line managers' enabled their teams to freely express voice over work issues. The fourth and final section asked participants to reflect on their experiences of the impact of the economic crisis on their own ability to freely express concerns to senior managers/owners.

\section{Data analysis}

Data was analyzed using thematic analysis to help us identify, analyze, interpret and report patterns (themes) within data (Roulston, 2001). The benefits of using thematic analysis are theoretical freedom and flexibility for providing complex accounts of data (Braun and Clarke, 2006). The coding scheme was developed through an inductive process (Dutton et al., 1997) through which both authors independently engaged in the coding process and checked for replication to ensure inter-rater reliability as is appropriate with semi-structured interviews (Morse, 1997). Themes identified were integrally linked to the data themselves (Patton, 2015) and were not guided by themes simply identified by prior research (Braun and Clarke, 2006). We reviewed the transcripts for underlying and revealing themes relating to (i) line managers' perception of the impact of crisis on daily management of staff (impact on work environment and on their role as managers), (ii) line managers' approach to employee voice within the teams they managed, and (iii) line managers' approach to expressing concerns to senior managers/owners. For an overview of key themes and associated codes see Table 3.

--Insert Table 3 about here--

After conducting the in-depth analysis, we attempted to interpret and theorize the patterns in relation to previous literature. The final part of our analysis involved a compare-contrast 
Prouska, R. and Psychogios, A. (forthcoming). Should I say something? A framework for understanding silence from a line manager's perspective during an economic crisis. Economic and Industrial Democracy.

between the findings of the two research phases in order to explore similarities/differences in how our participants discussed issues of voice/silence. Four criteria for evaluating interview quality were employed: (i) internal validity, by drawing on different literatures to discuss findings and by depicting data in tables to facilitate analysis; (ii) construct validity, by conducting interviews with line managers from various functions to gain insights into multiple perspectives and by presenting preliminary findings and conclusions to interviewees in order to get feedback and check the validity of interpretations; (iii) external validity, by collecting data from multiple participants across two time periods, and (iv) reliability, by developing and using an interview guide, developing interview transcripts and field notes, and documenting the data coding and analysis procedure.

\section{Findings and discussion}

We conducted our study in two time periods during the Greek economic crisis and this allowed us to reveal some very interesting findings in respect to silence from a line management perspective during the Greek economic crisis. This section presents our findings in each of the two phases of data collection and discusses them in relation to the relevant literature.

\section{Silence over the short-term}

A pragmatic reaction to the crisis. In the first phase of data collection, line managers discussed how they remained silent over work issues when communicating with their teams and senior managers/owners because they considered this a pragmatic approach in dealing with the difficulties the economic crisis presented to everyday business operations. Line managers supported organizational decisions, such as for downsizing, overtime, and pay 
Prouska, R. and Psychogios, A. (forthcoming). Should I say something? A framework for understanding silence from a line manager's perspective during an economic crisis. Economic and Industrial Democracy.

reductions etc., rationalized changes and explained their necessity to their teams. For example, line managers referred to how they communicated to their teams the need for everyone to be engaged at their work because the crisis had created a new reality requiring everyone's collaboration to overcome it. We, therefore, find more communication than voice, as is typical in small enterprises (Wilkinson et al., 2007). When prompted to explain this pragmatic approach, line managers made reference to messages they, themselves, had received from senior managers/owners who called for collaboration and acceptance of new work arrangements in order to overcome the financial difficulties. In this respect, line managers' role in promoting voice within their teams was inhibited by the pressing goals set upon them by senior managers/owners (Fenton-O'Creevy, 2001). At the same time, the message from the top was one of compliance, which would make them adopt harder approaches to managing their own staff than adopt employee involvement ones (Wilkinson et al., 1993). In addition, with the economy being on the verge of collapse and the constant news about the worsening employment market conditions, line managers themselves would also feel uncertain over their own jobs within this climate (Wilkinson et al., 2012).

In terms of their own ability to express voice to senior managers/owners, line managers' silence observed at this first phase of data collection is similar to the sportsmanship typology of silence (Organ, 1988; Van Dyne et al., 2003) which explains the willingness to tolerate difficulties at work without complaining. It is also similar to cooperative silence (Wang et al., 2012) which refers to remaining silent about issues which may disturb the functioning of the workplace. Line managers are not only willing to tolerate difficulties and keep quiet over complaints they may have about how the crisis has affected their day to day operations, but they are also communicating the need to support the organization within their teams. Table 4 below provides indicative quotes of line managers' silence based on pragmatism. 
Prouska, R. and Psychogios, A. (forthcoming). Should I say something? A framework for understanding silence from a line manager's perspective during an economic crisis. Economic and Industrial Democracy.

--Insert Table 4 about here--

Hope against hope. During the first phase of data collection, line managers also discussed how they, themselves, remained silent over issues that concerned them in their communications with staff. They based this behavior on hope that the negative impact of the crisis on business operations was only short-termed and that the situation would soon change if they concentrated on implementing the changes decided upon by the organization.

This type of silence exhibited by line managers is similar to loyalty (Hirschman, 1970) which refers to the practice of not speaking up, hoping that the situation will improve in the near future. Table 5 below provides indicative quotes of line managers' silence based on hope.

--Insert Table 5 about here--

\section{Silence over the long-term}

Crisis and disengagement at work. In the second phase of data collection, line managers felt disengagement which was fueled by demotivation and low morale. Line managers discussed how they were willing to stay silent and not encourage voice amongst the staff they managed because they believed that speaking up would not make any difference. Some line managers acknowledged that they knew their staff were worried about the long-term duration of the crisis, but felt unable to engage with senior management/owners over this issue as they did not believe that anything they would say could make a difference. They discussed how they believed that the crisis is beyond anyone's control, including senior managers/owners. This brings to the surface the role of senior managers/owners in disempowering line 
Prouska, R. and Psychogios, A. (forthcoming). Should I say something? A framework for understanding silence from a line manager's perspective during an economic crisis. Economic and Industrial Democracy.

managers from voice (Barry and Wilkinson, 2016) through the way they communicated the impact of the crisis on the business and on the inevitable goals set to line managers. This also seems to be the point in our research when line managers realize the tensions caused by their dual role of supervisors and supervisees in their organizations. They seemed to understand their team's concerns and even agreed with them, but felt unable to effectively communicate these issues to senior managers/owners. Therefore, we can argue that their role as intermediaries between their subordinates and senior managers/owners (Detert and Trevino, 2016) was hindered by messages from the top which were dictated to them.

Because their disengagement originates from their own realization and ensuing belief that they are unable to effect change, this type of line managers' silence has similarities with ineffectual silence (Brinsfield, 2013; Morrison and Milliken, 2000; Pinder and Harlos, 2001; Van Dyne et al., 2003) referring to the perception that speaking up is not useful as a tool in effecting change. In addition, relative literature has discussed acquiescence silence (Pinder and Harlos, 2001; Van Dyne et al., 2003), a concept based on resignation and denoting a deeply-felt acceptance of and compliance to the organizational circumstances, a submission to the situation and limited awareness that alternatives exist. This inner resignation from the situation makes line managers disengage from the process of facilitating voice amongst their staff, or expressing voice themselves (Denham et al., 1997; Wilkinson et al., 2004). This is similar to disengaged silence, a type of silence discussed in the literature as silence caused by disengagement, partially overlapping with the acquiescent dimension of silence as proposed by Van Dyne et al. (2003) (Brinsfield, 2013). Table 6 below provides indicative quotes of line managers' silence based on disengagement.

--Insert Table 6 about here-- 
Prouska, R. and Psychogios, A. (forthcoming). Should I say something? A framework for understanding silence from a line manager's perspective during an economic crisis. Economic and Industrial Democracy.

Cynical reaction to crisis. Most interestingly, during the second phase of data collection, we found evidence of line managers' encouragement of silence at work due to instilled cynicism over the organization's constantly altering decisions which actually led to worsening working conditions throughout the period of crisis. An underlying element in this type of silence is a broader lack of trust towards how the government has dealt with the crisis, how the media has portrayed the crisis, and the extent to which, consequently, senior managers/owners have used the pretext of the impact of the crisis on business operations during this time. Line managers discussed their lack of trust towards senior managers/owners, particularly questioning whether the crisis has indeed had such a profound impact on the business as portrayed by senior managers/owners in the previous years, or whether the crisis situation has to some extent been exploited by them in order to further reduce business costs. However, this lack of trust towards senior managers/owners, creates fear of consequences (Prouska and Psychogios, 2016) making line managers to remain silent over issues that may concern them, while this silence also filters through to the way they manage their staff. Table 7 provides indicative quotes of line managers' silence based on cynicism.

--Insert Table 7 about here--

Given that current employee silence typologies do not explicitly address silence as an outcome of lack of trust (cynicism), we propose cynical silence as a new typology relevant to economic crisis contexts and further conceptualize it in the next section.

Cynical silence. Concepts and typologies of silence have focused on a variety of causes of silence. Literature in the field has explored how the manifestation of silence can be caused by a social pressure for conformity, some hope that the situation will improve, a reluctance to 
Prouska, R. and Psychogios, A. (forthcoming). Should I say something? A framework for understanding silence from a line manager's perspective during an economic crisis. Economic and Industrial Democracy.

hear or be the conveyer of bad news, a willingness to be a good organizational citizen, fear, belief that voice is futile, acceptance or caused by deviant behavior (for an overview see Brinsfield, 2014). Particularly for typologies relevant to an economic crisis context, Prouska and Psychogios (2016) propose three key categories of silence (see Table 1). Firstly, silence caused due to fear of consequences (defensive silence, relational silence, climate of silence). Secondly, silence caused as a response to the perceived duration of the crisis (sportsmanship, cooperative silence, ineffectual silence, acquiescence silence, disengaged silence). And thirdly, silence caused because it is considered as the norm (social empathy silence, climate of fear, habituated silence).

Although our study found some of these typologies to be present, silence caused by cynicism, or cynical silence, is a new typology which our study is proposing as an addition to existing employee silence typologies in relation to an economic crisis context. Although the idea of studying cynicism and lack of trust as a cause for employee silence is not new (Donaghey et al., 2011), research has not dealt with this type of silence in depth, particularly when such cynicism and lack of trust are created by the broader economic context of a longterm crisis. Cynicism is an acquired belief that other people are generally selfish and dishonest and expresses one's a lack of trust that another party will act selflessly and honestly. We, therefore, define cynical silence at the workplace as a type of silence caused by an employee's perception (in our case, line managers' perception) that organizational leaders (in our case senior managers/business owners) are selfish and dishonest in the way they communicate with them the key organizational developments (in our case, ramifications and implications about the true and 'real' impact of the economic crisis on the business). Employee silence can be considered as a cynical reaction which is further fueled by an underlying fear of the consequences (as discussed by Prouska and Psychogios, 2016). This type of silence develops over the long-term (and this is why we identified this particular type 
Prouska, R. and Psychogios, A. (forthcoming). Should I say something? A framework for understanding silence from a line manager's perspective during an economic crisis. Economic and Industrial Democracy.

during the second phase of data collection), as lack of trust accumulates over time. Figure 1 presents our framework for understanding silence in an economic crisis context and from a line manager's perspective. The next section concludes our paper by summarizing the key contributions of our study to the employee silence literature and by suggesting avenue for further research.

--Insert Figure 1 about here--

\section{Conclusion}

This study explored how line managers experience voice and silence in the workplace from their own perspective and organizational position. Current research on silence has so far mostly focused on the employee perspective (Brinsfield, 2014). Some research has looked at the employers' perspective (Willman et al., 2006) and the leaders' role in promoting or inhibiting voice at work (Detert and Trevino, 2010; Kranz and Steger, 2013; Morrison, 2014; Xu et al., 2015). However, literature directly studying employee silence in times of economic crisis is scarce (with the exception of Kranz and Steger, 2013; Prouska and Psychogios, 2016; Schlosser and Zolin, 2012). Our study, therefore, adds to the existing body of knowledge. We explored two research questions: 1) What is the role of line managers in promoting or inhibiting voice within the teams they manage during a period of economic crisis? 2) How do line managers perceive the impact of the economic crisis on their ability to express dissatisfaction, complaint or concern to senior managers/owners?

In relation to the first research question, our study ascertained that line managers were indeed inhibited in their role to act as intermediaries between their subordinates and senior managers/owners (Detert and Trevino, 2010), and therefore, willingly or unwillingly, in turn, inhibited the expression of voice within their own teams. The messages they were receiving 
Prouska, R. and Psychogios, A. (forthcoming). Should I say something? A framework for understanding silence from a line manager's perspective during an economic crisis. Economic and Industrial Democracy.

from the top called for compliance, collaboration and acceptance of new work arrangements due to the worsening financial difficulties, while they were pressured to perform to higher standards (Fenton-O'Creevy, 2001). This pressure made them adopt harsher managerial approaches within their teams (Wilkinson et al., 1993) in the short-term, while in the longterm, resulted in making them feel disempowered rather than catalysts of voice (Barry and Wilkinson, 2016). Their role as catalysts in facilitating voice was further inhibited by their own uncertainty over their job security during the economic crisis period (Wilkinson et al., 2012). In this respect, our study contributes to our understanding of the role line managers play in inhibiting voice within their teams when the economic context puts pressure to small organizations to perform.

In relation to the second research question, we explored the line managers' own ability to express dissatisfaction, complaint or concern to senior managers/owners. At the first phase of data collection we saw how line managers adopted a pragmatic approach by trying to deal with the reality of the economic situation. They were pressuring employees to work and perform and to avoid complains. They believed that silence was a pragmatic solution and hoped that the crisis might be short-lived, therefore justifying a 'do as you are told' approach to help the organization overcome the dire situation. However, in the second phase of data collection we found that line managers adopted a disengaged approach fueled by a lack of trust towards senior managers/owners, giving up the hope that the impact of the crisis would be short lived. Line managers were silent over issues that concerned them due to their own disengagement (demotivation and low morale), and most interestingly, due to their own adopted cynicism.

Our study contributes to the enrichment of silence typologies, by proposing the existence of a new type or form of silence, which we termed cynical silence. We defined it as a type of employee silence which gradually develops and refers to behavioral silence caused 
Prouska, R. and Psychogios, A. (forthcoming). Should I say something? A framework for understanding silence from a line manager's perspective during an economic crisis. Economic and Industrial Democracy.

by a belief that people are generally selfish and dishonest and implies a lack of trust that another party will act selflessly and honestly at a given time. It is the lack of trust in senior managers/owners which is inhibiting line managers from raising their own voice to the top. Cynicism can result to disengagement, therefore making disengagement a potentially debilitating factor for the organization as a whole. Indeed, we observed ineffectual/acquiescence/disengaged silence in the second phase of data collection (see Figure 1). However, we also observed silence caused by cynicism, specifically relating to a lack of trust towards senior managers/owners caused by a perception that organizational leaders are selfish and dishonest in the way they communicate about the real impact of the economic crisis on their business and, consequently, on working conditions. These circumstances in turn cause line managers' silence as a cynical reaction, which is further fueled by a fear of the consequences (as discussed by Prouska and Psychogios, 2016).

Our study adds the element of 'cynicism' to the currently established employee silence typologies (Brinsfield, 2014) and the employee silence typologies relevant to an economic crisis context (Prouska and Psychogios, 2016 and Table 1). Prouska and Psychogios (2016) discussed the implications of social empathy silence, a type of silence which develops in the short-term of an economic crisis and relates to people's unwillingness to express their opinions on socioeconomic issues when they perceive themselves belonging to the minority, when this belief is largely shaped by the media and their other social interactions, and on people's empathetic fear on behalf of others. Examining 'media and other social interactions' through the lens of our study, our participants also referred to not trusting the government and the media in the way the crisis has been portrayed, and further discussed their lack of trust towards senior managers/owners of the businesses. This lack of trust manifests itself as cynicism, or cynical silence, while fear of consequences still plays a key role in exasperating this attitude. 
Prouska, R. and Psychogios, A. (forthcoming). Should I say something? A framework for understanding silence from a line manager's perspective during an economic crisis. Economic and Industrial Democracy.

Beyond our study's contributions noted above, we do recognize that this study has certain limitations. The sample of participants is rather small and, one might argue, not representative. However, the aim of this paper aspires to initiate a discussion around how line managers experience silence from their own perspective and organizational position in a crisis context, providing interesting empirical data from a context (Greece) where long-term crisis has challenged organizational survival. Another limitation is associated with the methods used. A qualitative study can offer good insights of participants' responses, however a quantitative investigation based on a survey could shed more light on the issues under examination.

Our findings create new directions for employee silence theory. Initially, future research can further explore the dual role played by line managers and the impact of this on promoting or inhibiting voice within the teams during an economic crisis. On a second stage, research can further explore senior managers/owners' role in making line managers cynically silent. Two questions arise: Are senior managers'/owners' as a matter of fact using the crisis as a pretext and manipulate the situation to their own benefit, as many line managers seem to suspect? Or are senior managers/owners truly unable to reduce the negative impact the crisis has had on employees? A question still remains over whether senior managers/owners openly communicate over issues concerning the business in times of economic crisis (Psychogios et al., 2016). Our study focused on the line managers' point of view, but further research is needed from a line/middle-managers' perspective, as well as from a senior managers'/owners' perspective in small enterprises in order to re-conceptualize cynical silence, in respect as to how it develops over time.

Overall, our findings and proposed framework are important in helping small enterprises understand the origins and development of silence across different organizational levels. Through our qualitative research we uncovered a new silence typology and proposed a 
Prouska, R. and Psychogios, A. (forthcoming). Should I say something? A framework for understanding silence from a line manager's perspective during an economic crisis. Economic and Industrial Democracy.

framework for understanding silence in times of crisis from a line manager's perspective. However, the research design does not allow for generalizations of results. Future research could look at quantitatively studying silence at work, how it manifests at different organizational levels and how it develops over time.

\section{Funding}

This research received no specific grant from any funding agency in the public, commercial, or not-for-profit sectors.

\section{Declaration of Conflicting Interests}

The author(s) declared no potential conflicts of interest with respect to the research, authorship, and/or publication of this article.

\section{References}

Allport F (1924) Social Psychology. Boston: Houghton Mifflin.

Arghyrou M and Tsoukalas J (2010) The Greek debt crisis: Likely causes, mechanics and outcomes. The World Economy 34(2): 173-191.

Bae KS, Chuma H, Kato T, Kim DB and Ohashi I (2011) High performance work practices and employee voice: A comparison of Japanese and Korean workers. Industrial Relations: A Journal of Economy and Society 50(10): 1-29. 
Prouska, R. and Psychogios, A. (forthcoming). Should I say something? A framework for understanding silence from a line manager's perspective during an economic crisis. Economic and Industrial Democracy.

Barry M and Wilkinson A (2016) Pro-social or pro-management? A critique of the conception of employee voice within organizational behavior. British Journal of Industrial Relations 54(2): 261-284.

Beer M and Eisenstat R (2000) The silent killers of strategy implementation and learning. Sloan Management Review 41(4): 29-40.

Behrends T (2007) Recruitment practices in small and medium size enterprises: An empirical study among knowledge-intensive professional service firms. Management Review 18(1): 5574.

Bowen F and Blackmon K (2003) Spirals of silence: The dynamic effects of diversity on organizational voice. Journal of Management Studies 40(6): 1393-1417.

Braun V and Clarke V (2006) Using thematic analysis in psychology. Qualitative Research in Psychology 3(2): 77-101.

Brewster C, Brookes M and Gollan PJ (2015) The institutional antecedents of the assignment of HRM responsibilities to line managers. Human Resource Management 54(4): 577-597.

Brinsfield CT (2014) Employee voice and silence in organizational behavior. In Wilkinson A, Donaghey J, Dundon T and Freeman B (eds) Handbook of Research on Employee Voice. Cheltenham: Edward Elgar Publishing, pp. 114-131.

Brinsfield CT (2013) Employee silence motives: Investigation of dimensionality and development of measures. Journal of Organizational Behavior 34(5): 671-697.

Bryman A and Bell E (2003) Business Research Methods. Oxford: Oxford University Press. 
Prouska, R. and Psychogios, A. (forthcoming). Should I say something? A framework for understanding silence from a line manager's perspective during an economic crisis. Economic and Industrial Democracy.

Chatrakul Na Ayudhya U, Prouska R and Beauregard TA (2017) The impact of global economic crisis and austerity on quality of working life and work-life balance: A capabilities perspective. European Management Review, Early View 17 July 2017, doi: 10.1111/emre. 12128.

Chung $\mathrm{H}$ and Van Oorschot W (2011) Institutions versus market forces: Explaining the employment insecurity of European individuals during (the beginning of) the financial crisis. Journal of European Social Policy 21(4): 287-301.

Conlee MC and Tesser A (1973) The effects of recipient desire to hear on news transmission. Sociometry 36(4): 588-599.

Conway N, Kiefer T, Hartley J and Briner RB (2014) Doing more with less? Employee reactions to psychological contract breach via target similarity or spillover during public sector organizational change. British Journal of Management 25(4): 737-754.

Cuellar MJ, Keil M and Johnson RD (2006) The deaf effect response to bad news reporting in information systems projects. E-Service Journal 5(1): 75-97.

Denham N, Ackers P and Travers C (1997) Doing yourself out of a job? How middle managers cope with empowerment. Employee Relations 19(2): 147-159.

Detert JR and Edmondson AC (2011) Implicit voice theories: Taken-for-granted rules of selfcensorship at work. Academy of Management Journal 54(3): 461-488

Detert JR and Trevino LK (2010) Speaking up to higher ups: How supervisor and skip-level leaders influence employee voice. Organization Science 21(1): 249-270. 
Prouska, R. and Psychogios, A. (forthcoming). Should I say something? A framework for understanding silence from a line manager's perspective during an economic crisis. Economic and Industrial Democracy.

Donaghey J, Cullinane N, Dundon T and Wilkinson A (2011) Reconceptualizing employee silence: Problems and prognosis. Work, Employment and Society 25(1): 51-67.

Dundon T and Gollan PJ (2007) Re-conceptualizing voice in the non-union workplace. The International Journal of Human Resource Management 18(7): 1182-1198.

Dundon T, Wilkinson A, Marchington M and Ackers P (2005) The management of voice in non-union organisations: Managers' perspectives. Employee Relations 27(3): 307-319.

Dutton JE, Ashford SJ, O’Neill RM, Hayes E and Wierba EE (1997) Reading the wind: How middle managers assess the context for selling issues to top managers. Strategic Management Journal 18(5): 407-425.

ETUI (2016) Greece - Workplace representation. Available at: www.workerparticipation.eu/National-Industrial-Relations/Countries/Greece/Workplace-Representation (accessed 16-12-2016).

Eurostat (2017). GDP and main aggregates estimate for the second quarter of 2017. Luxembourg: Eurostat. September 2017.

Featherstone K (2008) Varieties of capitalism and the Greek case: Explaining the constraints on domestic reform. GreeSE Paper No 11, Hellenic Observatory, Papers on Greece and Southeast Europe.

Fenton-O'Creevy M (2001) Employee involvement and the middle manager: saboteur or scapegoat? Human Resource Management Journal 11(1): 24-40.

Floyd WS and Wooldridge B (2000) Building Strategy from the Middle: Reconceptualizing Strategy Process, Foundations for Organizational Science Series. London: Sage 
Prouska, R. and Psychogios, A. (forthcoming). Should I say something? A framework for understanding silence from a line manager's perspective during an economic crisis. Economic and Industrial Democracy.

Gersick CJG, Bartunek JM and Dutton JE (2000) Learning from academia: The importance of relationships in professional life. Academy of Management Journal 43(6): 1026-1044.

Gilbert C, De Winne S and Sels L (2011) The influence of line managers and HR department on employees' affective commitment. The International Journal of Human Resource Management 22(8): 1618-1637.

Gilman M, Raby S and Pyman A (2015) The contours of employee voice in SMEs: The importance of context. Human Resource Management Journal 25(4): 563-579.

Gruys ML and Sackett PR (2003) Investigating the dimensionality of counterproductive work behavior. International Journal of Selection and Assessment 11(1): 30-42.

Harvey JB (1974) The Abilene paradox: The management of agreement. Organizational Dynamics 3(1): 63-80.

Henriksen J and Dayton E (2006) Organizational silence and hidden threats to patient safety. Health Services Research 41(4): 1539-1554.

Hirschman AO (1970) Exit, Voice and Loyalty: Responses to Declines in Firms, Organizations and States. Cambridge, MA: Harvard University Press.

Huber G and Power DJ (1985) Research notes and communications - Retrospective reports of strategic managers: Guidelines for increasing their accuracy. Strategic Management Journal 6(2): 171-180.

Ioannou C and Papadimitriou K (2013) Collective bargaining in Greece in 2011 and 2012: Trends, breakthroughs and prospects (in Greek). Athens: OMED (Organization for Mediation and Arbitration). 
Prouska, R. and Psychogios, A. (forthcoming). Should I say something? A framework for understanding silence from a line manager's perspective during an economic crisis. Economic and Industrial Democracy.

Janis IL (1972) Groupthink: Psychological Studies of Policy Decisions and Fiascoes. Boston: Houghton Mifflin.

Kornelakis A and Voskeristian H (2014) The transformation of employment regulation in Greece: Towards a dysfunctional liberal market economy? Relations Industrielles/Industrial Relations Quarterly Review 69(2): 344-365.

Kosmidou KV, Kousenidis DV and Negakis CI (2015) The impact of the EU/ECB/IMF bailout programs on the financial and real sectors of the ASE during the Greek sovereign crisis. Journal of Banking \& Finance 50: 440-454.

Kotey B and Slade P (2005) Formal human resource management practices in small growing firms. Journal of Small Business Management 43(1): 16-40.

Kouretas G and Vlamis P (2010) The Greek crisis: Causes and implications. Panoeconomicus 57(4): 391-404.

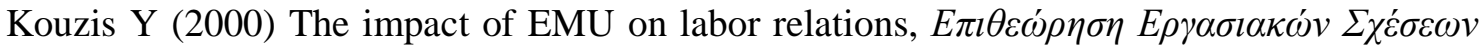
(in Greek), 18: 57-66.

Kranz O and Steger T (2013) The impact of the global financial crisis on employee participation - two German case studies. International Journal of Manpower 34(3): 252-270.

Landau J (2009) To speak or not to speak: predictors of voice propensity. Journal of Organizational Culture, Communications and Conflict 13(1): 35-54.

Latane B and Darley JM (1968) Group inhibition of bystander intervention in emergencies. Journal of Personality and Social Psychology 10(3): 215-221. 
Prouska, R. and Psychogios, A. (forthcoming). Should I say something? A framework for understanding silence from a line manager's perspective during an economic crisis. Economic and Industrial Democracy.

Lepine JA and Van Dyne L (1998) Predicting voice behavior in work groups. Journal of Applied Psychology 83(6): 853-868.

Marchington M and Suter J (2013) Where informality really matters: Patterns of employee involvement and participation (EIP) in a non-union firm. Industrial Relations 52(S1): 284313.

Marlow S and Gray C (2005) Information and consultation in small and medium-sized enterprises. In: Storey J (ed.) Adding Value through Information and Consultation. Basingstoke: Palgrave Macmillan, pp. 21-28.

Milliken FJ, Morrison EW and Hewlin PF (2003) An exploratory study of employee silence: Issues that employees don't communicate upward and why. Journal of Management Studies 40(6): 1453-1476.

Morrison EW (2014) Employee voice and silence. Annual Review of Organizational Psychology and Organizational Behavior 1: 173-197.

Morrison EW and Rothman NB (2009) Silence and the dynamics of power. In Edwards MS and Greenberg J (eds) Voice and Silence in Organizations. Bingley: Emerald Group, pp. 111133.

Morrison EW and Milliken FJ (2000) Organizational silence: A barrier to change and development in a pluralistic world. Academy of Management Review 25(4): 706-725.

Morse JM (1997) Editorial - Perfectly healthy, but dead: The myth of inter-rater reliability. Qualitative Health Research 7(4): 445-447. 
Prouska, R. and Psychogios, A. (forthcoming). Should I say something? A framework for understanding silence from a line manager's perspective during an economic crisis. Economic and Industrial Democracy.

Ng TWH and Feldman DC (2011) Employee voice behavior: A meta-analytic test of the conservation of resources framework. Journal of Organizational Behavior 33(2): 216-234.

Noelle-Newmann R (1974) The spiral of silence: A theory of public opinion. Journal of Communication 24(2): 43-51.

OECD (2016). OECD Economic Surveys - Greece - March 2016 Overview. Available at: www.oecd.org/eco/surveys/economic-survey-greece.htm (accessed 29-09-2017).

OECD (2009), The impact of the global crisis on SME and entrepreneurship financing and policy responses. Available at: https://www.oecd.org/cfe/smes/43183090.pdf (accessed 2909-2017)

O’Reilly J, Lain D, Sheehan M, Smale B and Stuart M (2011) Managing uncertainty: The crisis, its consequences and the global workforce. Work, Employment and Society 25(4): 581595.

Organ DW (1988) Organizational Citizenship Behavior: The Good Soldier Syndrome. Lexington, MA: Lexington Books.

Patton MQ (2015) Qualitative research \& evaluation methods: Integrating theory and practice. Thousand Oaks: Sage Publications.

Peirce E, Smolinski CA and Rosen B (1998) Why sexual harassment complaints fall on deaf ears. Academy of Management Executive 12(3): 41-54.

Pinder CC and Harlos KP (2001) Employee silence: Quiescence and acquiescence as response to perceived injustice. In Ferris GR (ed), Research in Personnel and Human Resources Management. Greenwich: JAI Press, pp. 331-369. 
Prouska, R. and Psychogios, A. (forthcoming). Should I say something? A framework for understanding silence from a line manager's perspective during an economic crisis. Economic and Industrial Democracy.

Prouska R and Psychogios A (2016) Do not say a word! Conceptualizing employee silence in a long-term crisis context. The International Journal of Human Resource Management, published online 01August 2016, doi: 10.1080/09585192.2016.1212913.

Prouska R, Psychogios A and Rexhepi Y (2016) Rewarding employees in economies under crisis and transition: The application of the total reward model in south-eastern European SMEs. Personnel Review 45(6): 1259-1280.

Prouska R and Kapsali M (eds) (2011) Business and Management Practices in Greece: A Comparative Context. London: Palgrave Macmillan.

Psillaki M and Eleftheriou K (2015) Trade credit, bank credit, and flight to quality: Evidence from French SMEs. Journal of Small Business Management, 53(4): 1219-1240.

Psychogios A, Nyfoudi M, Theodorakopoulos N, Szamosi L and Prouska R. (2017) Many hands lighter work? Deciphering the relationship between Adverse Working Conditions and Organization Citizenship Behaviors in SMEs during a severe economic crisis. British Journal of Management, Early View 3 November 2017, doi: 10.1111/1467-8551.12245.

Psychogios A, Szamosi L, Prouska R and Brewster C (2016) A three-fold framework for understanding HRM practices in south-eastern European SMEs. Employee Relations, 38(3): 310-331.

Psychogios A and Wood G (2010) Human resource management in Greece in comparative perspective: Alternative institutionalist perspectives and empirical realities. The International Journal of Human Resource Management 21(14): 2614-2630. 
Prouska, R. and Psychogios, A. (forthcoming). Should I say something? A framework for understanding silence from a line manager's perspective during an economic crisis. Economic and Industrial Democracy.

Psychogios A, Alexandris K and Onofrei A (2008) Addressing individual and organizational factors influencing middle managers synthesising role in lnowledge creation and diffusion. International Journal of Learning \& Intellectual Capital 5(2): 208-222.

Rosen S and Tesser A (1971) On the reluctance to communicate undesirable information (the MUM effect): A field study. Psychological Reports 29(2): 651-654.

Roulston K (2001) Data analysis and theorizing as ideology. Qualitative Research 1(3): 279302.

Russell H and McGinnity F (2014) Under pressure: The impact of recession on employees in Ireland. British Journal of Industrial Relations 52(2): 286-307.

Sameer M and Ozbilgin MF (2014) Employee voice in the SME context. In Wilkinson A, Donaghey J, Dundon T and Freeman B (eds) Handbook of Research on Employee Voice. Cheltenham: Edward Elgar Publishing, pp. 410-420.

Samitas A and Polyzos S (2016) Freeing Greece from capital controls: Were the restrictions enforced in time? Research in International Business and Finance 37(May): 196-213.

Saunders DM, Sheppard B, Knight V. and Roth J (1992) Employee voice to supervisors. Employee Responsibilities and Rights Journal 5(3): 241-257.

Schlosser F and Zolin R (2012) Hearing voice and silence during stressful economic times. Employee Relations 34(5): 555-573.

Strauss G (1998) An overview. In Heller F, Pusic E, Wilpert B and Strauss G (eds) Organizational Participation: Myth and Reality. Oxford: Oxford University Press, pp. 8-39. 
Prouska, R. and Psychogios, A. (forthcoming). Should I say something? A framework for understanding silence from a line manager's perspective during an economic crisis. Economic and Industrial Democracy.

Tangirala S and Ramanujam R (2008) Employee silence on critical work issues: The cross level effects of procedural justice climate. Personnel Psychology 61(1): 37-68.

Teague P and Roche WK (2013) Recessionary bundles: HR practices in the Irish economic crisis, Human Resource Management Journal 24(2): 176-192.

Trow D B (1961) Executive succession in small companies, Administrative Science Quarterly 6(2): $228-239$.

Van Dyne L, Ang S and Botero IC (2003) Conceptualizing employee silence and employee voice as multidimensional constructs. Journal of Management Studies 40(6): 1359-1392.

Wang AC, Hsieh HH, Tsai CY and Cheng BS (2012) Does value congruence lead to voice? Cooperative voice and cooperative silence under team and differentiated transformational leadership. Management and Organization Review 8(2): 341-370.

Wengraf T (2001) Qualitative Research Interviewing: Biographic, Narrative and Semistructured Methods. London: Sage Publications.

Wilkinson A, Dundon T and Marchington M (2012) Employee involvement and voice. In Bach $\mathrm{S}$ and Edwards MR (eds) Managing Human Resources: Human Resource Management in Transition. Hoboken: John Wiley \& Sons, pp. 268-288.

Wilkinson A and Fay C (2011) New times for employee voice? Human Resource Management 50(1): 65-74.

Wilkinson A, Dundon T and Grugulis I (2007) Information but not consultation: Exploring employee involvement in SMEs. The International Journal of Human Resource Management 18(7): 1279-1297. 
Prouska, R. and Psychogios, A. (forthcoming). Should I say something? A framework for understanding silence from a line manager's perspective during an economic crisis. Economic and Industrial Democracy.

Wilkinson A, Dundon T, Marchington M and Ackers P (2004) Changing patterns of employee voice: Case studies from the UK and Republic of Ireland. The Journal of Industrial Relations 46(3): 298-322.

Wilkinson A (1999) Employment relations in SMEs. Employee Relations 22(3): 206-217.

Wilkinson A, Marchington M, Goodman J and Ackers P (1993) Refashioning industrial relations: The experience of a chemical company over the last decade. Personnel Review 22(2): 22-38.

Willman P, Bryson A and Gomez R (2006) The sound of silence: Which employers choose no employee voice and why? Socio-Economic Review 4(2): 283-299.

Wood G, Szamosi LT, Psychogios A, Sarvanidis S and Fotopoulou D (2015) Rethinking Greek capitalism through the lens of industrial relations reform: A view until the 2015 referendum. Relations Industrielles/Industrial Relations 70(4): 698-717.

$\mathrm{Xu}$ AJ, Loi R and Lam LW (2015) The bad boss takes it all: How abusive supervision and leader-member exchange interact to influence employee silence. The Leadership Quarterly 26(5): 763-774. 
Prouska, R. and Psychogios, A. (forthcoming). Should I say something? A framework for understanding silence from a line manager's perspective during an economic crisis. Economic and Industrial Democracy.

Figure 1. Framework for Understanding Silence during an Economic Crisis through a Line Manager's Perspective

\begin{tabular}{|c|c|c|}
\hline \multirow{3}{*}{ Types of Silence } & $\begin{array}{l}\text { Silence based on } \\
\text { pragmatism } \\
\text { sportsmanship / } \\
\text { cooperative silence }\end{array}$ & $\begin{array}{c}\text { Silence based on } \\
\text { disengagement } \\
\text { ineffectual silence / } \\
\text { acquiescence silence / } \\
\text { disengaged silence }\end{array}$ \\
\hline & $\begin{array}{c}\text { Silence based on hope } \\
\text { loyalty }\end{array}$ & $\begin{array}{l}\text { Silence based on } \\
\text { cynicism } \\
\text { cynical silence }\end{array}$ \\
\hline & short-term & long-term \\
\hline
\end{tabular}


Table 1. Typologies of Silence during Economic Crisis

\section{Type of Silence}

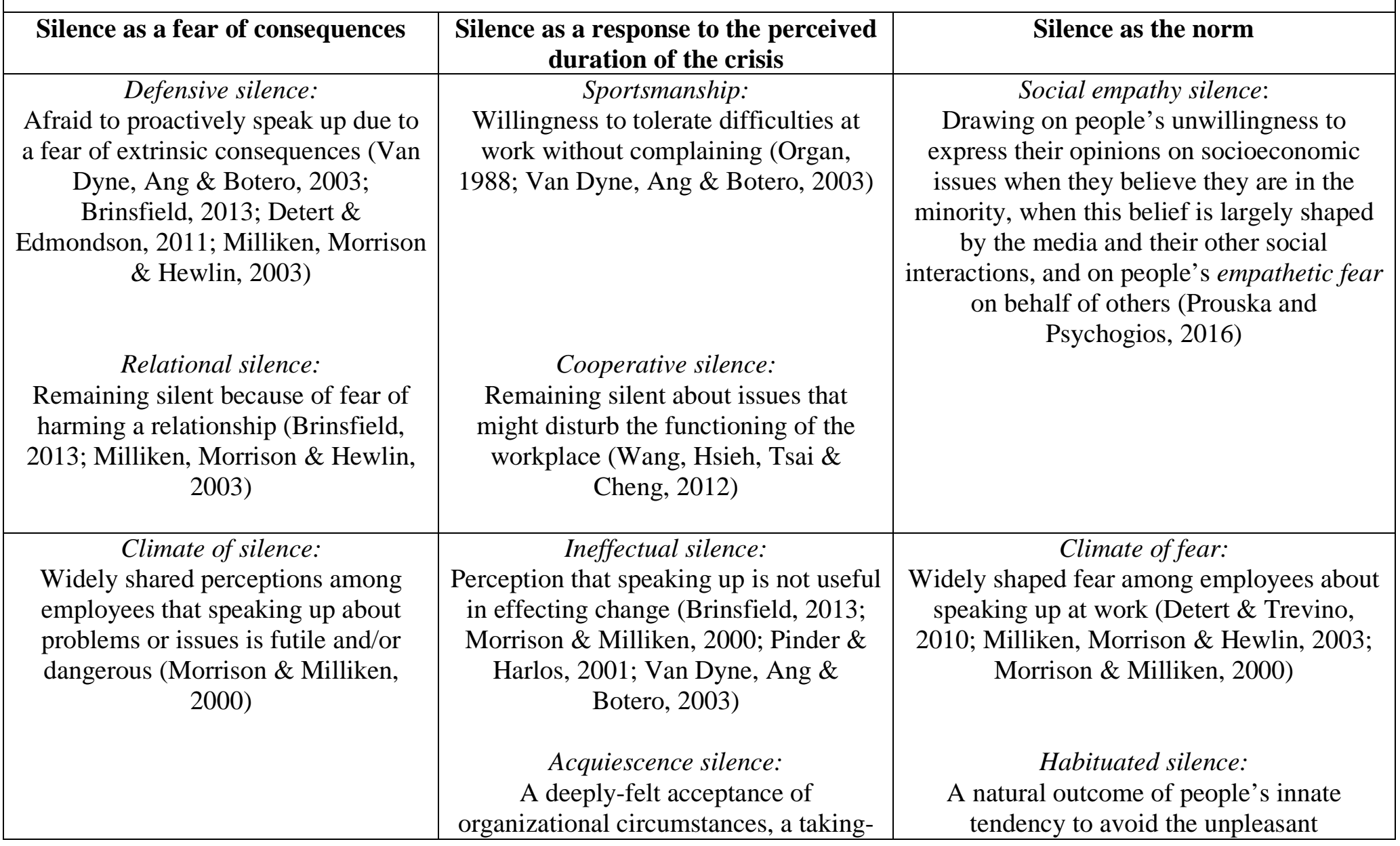




\begin{tabular}{|l|c|c|}
\hline & $\begin{array}{c}\text { for-granted of the situation and limited } \\
\text { awareness that alternatives exist. Based } \\
\text { on resignation, employees are passively } \\
\text { silent because they do not believe they } \\
\text { can make a difference (Pinder and } \\
\text { Harlos, 2001; Van Dyne, Ang \& } \\
\text { Botero, 2003) } \\
\text { 2000; Morrison \& Rothman, 2009) } \\
\text { Disengaged silence: } \\
\text { Based on disengagement, partially } \\
\text { overlapping with the acquiescent } \\
\text { dimension of silence as proposed by } \\
\text { Van Dyne, Ang \& Botero (2003) } \\
\text { (Brinsfield, 2013) }\end{array} \mid$ \\
\hline
\end{tabular}

Source: based on Prouska and Psychogios (2016) 
Prouska, R. and Psychogios, A. (forthcoming). Should I say something? A framework for understanding silence from a line manager's perspective during an economic crisis. Economic and Industrial Democracy.

Table 2. Overview of Businesses \& Employees Participating in the Study

\begin{tabular}{|c|c|c|c|c|c|}
\hline Industry & Sector & Size & $\begin{array}{l}\text { Years of } \\
\text { Operation }\end{array}$ & Location & Positon of interviewees \\
\hline \multirow{5}{*}{ Manufacturing } & Leather \& shoes & 15 & 15 & Thessaloniki & Operations manager* \\
\hline & Construction & 25 & 22 & Thessaloniki & Supplies manager \\
\hline & Building materials & 18 & 14 & Athens & Supervisor* \\
\hline & Leather \& shoes & 28 & 11 & Athens & Sales manager \\
\hline & Wood \& furniture & 32 & 19 & Athens & Production manager \\
\hline \multirow{12}{*}{ Retail } & Food wholesaler & 22 & 25 & Athens & Sales manager \\
\hline & Electronics retailer & 38 & 20 & Athens & Sales manager \\
\hline & Super market & 48 & 21 & Athens & HR manager* \\
\hline & $\begin{array}{l}\text { Clothes/garment } \\
\text { wholesaler }\end{array}$ & 33 & 13 & Thessaloniki & Product manager \\
\hline & Automotive retailer & 44 & 23 & Athens & Sales manager \\
\hline & Electronics retailer & 35 & 15 & Thessaloniki & Accounts manager \\
\hline & $\begin{array}{l}\text { Clothes/garment } \\
\text { wholesaler }\end{array}$ & 29 & 10 & Athens & Product manager \\
\hline & Food wholesaler & 33 & 17 & Athens & Quality manager* \\
\hline & Super market & 43 & 15 & Thessaloniki & Finance manager \\
\hline & Food wholesaler & 39 & 14 & Thessaloniki & Marketing manager* \\
\hline & Super market & 45 & 24 & Thessaloniki & Supplies manager \\
\hline & $\begin{array}{l}\text { Clothes/garment } \\
\text { wholesaler }\end{array}$ & 44 & 18 & Thessaloniki & HR manager \\
\hline \multirow{18}{*}{ Services } & Tourist agency & 25 & 14 & Athens & Marketing manager \\
\hline & Business consultancy & 22 & 12 & Thessaloniki & Public relations manager \\
\hline & Transportation & 39 & 12 & Athens & Logistics manager \\
\hline & $\begin{array}{l}\text { Information } \\
\text { technology }\end{array}$ & 45 & 11 & Athens & Marketing manager \\
\hline & Logistics & 49 & 15 & Thessaloniki & Accounts manager* \\
\hline & $\begin{array}{l}\text { Communication \& } \\
\text { advertising }\end{array}$ & 37 & 16 & Athens & Sales manager \\
\hline & Training services & 29 & 12 & Thessaloniki & Marketing manager \\
\hline & Logistics & 38 & 13 & Athens & IT manager \\
\hline & Tourist agency & 45 & 17 & Thessaloniki & Marketing \\
\hline & Printing \& publishing & 48 & 28 & Athens & HR manager \\
\hline & Business consultancy & 37 & 21 & Thessaloniki & Accounts manager \\
\hline & $\begin{array}{l}\text { Communication \& } \\
\text { advertising }\end{array}$ & 24 & 22 & Athens & Customer relations manager \\
\hline & Tourist agency & 32 & 32 & Thessaloniki & Sales manager \\
\hline & Logistics & 35 & 25 & Athens & Operations manager \\
\hline & $\begin{array}{l}\text { Banking, finance \& } \\
\text { insurances }\end{array}$ & 47 & 42 & Athens & HR manager \\
\hline & Business consultancy & 35 & 14 & Athens & Marketing manager \\
\hline & $\begin{array}{l}\text { Banking, finance \& } \\
\text { insurances }\end{array}$ & 27 & 41 & Thessaloniki & Marketing manager \\
\hline & Business consultancy & 49 & 18 & Athens & $\begin{array}{l}\text { Customer relations } \\
\text { manager* }\end{array}$ \\
\hline
\end{tabular}

* indicates that the participant had left the organization or that the business had closed down by Phase

II of the study. In such cases, we did not conduct interviews in Phase II in these organizations. 
Prouska, R. and Psychogios, A. (forthcoming). Should I say something? A framework for understanding silence from a line manager's perspective during an economic crisis. Economic and Industrial Democracy.

\section{Table 3. Key Themes and Associated Open Codes}

\begin{tabular}{l|l}
\hline \multicolumn{1}{c|}{ Core Themes } & \multicolumn{1}{c}{ Open Codes } \\
\hline $\begin{array}{l}\text { 1. Impact of crisis on daily } \\
\text { management of staff }\end{array}$ & $\begin{array}{l}\text { "downsizing", "layoffs/redundancies", "cost-cutting } \\
\text { strategy", "work intensification", "pay reduction", } \\
\text { "demotivation", "low morale", "job insecurity", "job } \\
\text { dissatisfaction", "low performance", "uncertainty of } \\
\text { future operations", "reduction of market share" }\end{array}$ \\
$\begin{array}{l}\text { 2. Practical stance to silence / } \\
\text { pragmatism }\end{array}$ & $\begin{array}{l}\text { "collaboration to overcome crisis", "convincing } \\
\text { communication (hard language) over management } \\
\text { decisions", "supporting management decisions", } \\
\text { "wide spread effects of crisis", "crisis as a new } \\
\text { reality", "rationalization of management decisions" }\end{array}$ \\
3. Hope / optimism & $\begin{array}{l}\text { "resilience/patience/putting up with the situation", } \\
\text { "acceptance of crisis", "support for the organization", } \\
\text { "collaboration", "hard work" } \\
\text { "low morale", "demotivation", "labor turnover", } \\
\text { "work intensification", "voice will not make a } \\
\text { difference", "powerlessness", "giving up" } \\
\text { "work intensification", "feelings of helplessness", } \\
\text { "fear of consequences", "no voice line managers-team } \\
\text { members", "no communication line managers-senior } \\
\text { managers/owners", "questioning strategies", "trust - } \\
\text { government", "trust - media", "trust - senior } \\
\text { managers/owners", "truth about crisis", "senior } \\
\text { managers/owners interests", "dishonest management", } \\
\text { "selfish management" }\end{array}$ \\
\hline Cynical reaction
\end{tabular}


Prouska, R. and Psychogios, A. (forthcoming). Should I say something? A framework for understanding silence from a line manager's perspective during an economic crisis. Economic and Industrial Democracy.

\section{Table 4. Indicative Quotes - Silence based on Pragmatism}

\section{Silence based on Pragmatism}

"I do not deny that lately, and especially due to the crisis, you may start using more 'hard' language to convince people regarding how critical the situation is. It is something that has become a new reality now in companies and people have to accept it... Yes we need to cut pay and everyone has to work overtime. There is no other solution and I need to explain this to my team." (Production manager; wood \& furniture, Athens)

"Most of the time I discuss with my employees the new situation in Greece, aiming at explaining to them the need to have more understanding and tolerance upon management's choices. We all need to work together and fight this situation... I can't see any other way out of this... At the same time I encourage them to discuss this with other people in the company. I know that by doing so, they can find more support amongst them." (HR manager; clothes/garment wholesaler, Thessaloniki)

"Of course it is a very difficult situation to be in. But what can we do about this? The crisis has affected all companies, and not just our business. Businesses are struggling, they are trying to survive. We need to be realistic here. Complaining will not help. We all need to concentrate on working together to overcome this situation." (Marketing manager; banking, finance \& insurances, Thessaloniki)

"...one of the main needs during this period of time is to try more by working and not talking. We need to rationalize our operations in order for the company to survive. I doubt whether the solution is to start complaining, so I tell this to my staff, I tell them about how serious the situation is and how we need to support our business regardless of harsh measures they need to implement." (Supplies manager; construction, Thessaloniki)

"There is simply too much work to be done now by every individual, since what five employees were doing before, today around three have to complete. So we need to concentrate on that and avoid creating more problems than those that we already need to face... Everyone needs to work together and this is what I tell my team." (Operations manager; logistics, Athens) 
Prouska, R. and Psychogios, A. (forthcoming). Should I say something? A framework for understanding silence from a line manager's perspective during an economic crisis. Economic and Industrial Democracy.

\section{Table 5. Indicative Quotes - Silence based on Hope}

\section{Silence based on Hope}

"I don't like the changes implemented. For example, I don't want my team to be overworked and underpaid. But let's not forget that I am affected too. No one is immune to what this crisis has done to businesses. But I do hope that perhaps if we are patient, and if we put up with this situation, eventually the crisis will end, things will become better." (Sales manager; leather \& shoes, Athens)

"There is no point in telling my team to fight against the situation, or for me to go against the owners. What we all need to do is accept what is happening and hope that it will end soon." (Sales manager; electronics retailer, Athens)

"I hope that the situation will soon change. I can see what the changes in our structure and the pay are doing to my team. But we all need to support the business now until the situation improves." (Product manager; clothes/garment wholesales, Athens)

"I am sure that the crisis will eventually pass. There will definitely be issues that we will need to overcome in future, but it will pass. So I need to say this to my team and explain the changes that we need to make and push them to work hard during this period." (Marketing manager; training services, Thessaloniki)

"I need to tell my staff to work hard and put effort in what they do regardless of the negative implications we have so far received because of this situation. We won't be in crisis forever anyway, so we should support the business in this time of need." (Supervisor; building materials, Athens) 
Prouska, R. and Psychogios, A. (forthcoming). Should I say something? A framework for understanding silence from a line manager's perspective during an economic crisis. Economic and Industrial Democracy.

\section{Table 6. Indicative Quotes - Silence based on Disengagement}

\section{Silence based on Disengagement}

“...I do not know how many more years we can sustain our business by constantly focusing on reducing cost. I have lost good employees because of this, and anyone remaining is overworked and underpaid, including myself. At first I was really trying to help this business by telling everyone that if we work hard, we will be able to overcome this situation. But I don't think so anymore and I know that encouraging my staff to speak up, or speaking up myself to the owners will not make a difference." (Production manager; wood \& furniture, Athens)

"We have hit rock bottom. There is no visible way out of this crisis and because of this I have started not to engage much with the owners of the company because I know that nothing I will say will change the situation. I know that my staff are very worried and I do not blame them... but I simply cannot help them, we are all part of this and complaining will not help." (Finance manager; super market, Thessaloniki)

"What this crisis has done to us is make us believe that no matter how much effort we put in and how much we try, there is nothing than we can change. So what is the point of speaking up and saying what is on your mind? What can you change? Nothing." (Marketing manager; information technology, Athens)

"When the crisis started the owners told us to be patient and work hard in order to help the business survive. I have been doing this and I have also been telling my team to do this. But this is not improving now and it will never do. There is nothing that I or my team can say about all the changes implemented that will make the owners change their mind, because we know that they are stuck in this situation too, so why bother?" (Customer relations manager; communications \& advertising, Athens)

"I can see it in the people, the staff, they have given up and accepted that things will not change now or for a very long time. They are trying to get on with this new way of working, and so have I." (HR manager; banking, finance \& insurances, Athens) 
Prouska, R. and Psychogios, A. (forthcoming). Should I say something? A framework for understanding silence from a line manager's perspective during an economic crisis. Economic and Industrial Democracy.

\section{Table 7. Indicative Quotes - Silence based on Cynicism}

\section{Silence based on Cynicism}

“...We have more and more work to do and it is constantly with fewer people, fewer resources and with many problems. They [company owners] say that it is the only option. They have been saying this for a very long time, I wonder if this is true or whether they are taking advantage of this whole situation. But I will not say anything to my team or to the owners. I will keep on repeating message I have been told to say; that we need to keep on working even if this is more hours with less money, because this is the situation now. Everyone is afraid and so am I.' (Production manager; wood \& furniture, Athens)

"I always supported the senior managers, they said it was a difficult time and for this reason I was telling everyone to work hard regardless of the changes we had to make so that the business could survive. But it's been so long now and I am wondering if the business should be trying to find a different solution to our problems than constantly pressing people to perform in this really bad environment here. But will I say this to them [refers to senior managers]? Of course not. And I cannot talk about this with my staff because of my difficult position." (Sales manager; automotive retailer, Athens)

"...There is no point in saying anything and continue fighting when you cannot change anything. I think the government has lied to us and I do not trust what the media have to say anymore and I am not sure I can trust the management of this company. I can see that the business is affected, but it is so easy to blame the crisis for everything. I don't see any actions from the company to try to help us [the employees] since the crisis began. All the negative consequences seem to be falling on us." (HR manager; printing \& publishing, Athens)

"With everything happening around me, family and friends losing their jobs, everyone earning less money, I do not feel it is my place to tell the owners how to run their business. Could they have done more for us? Possibly, but we will never know. So I cannot help my staff, because I cannot even help myself." (Logistics manager; transportation, Athens)

"The owners say that we still don't have enough money in our business to be able to pay people properly and that we still need to work hard. But tourism in Greece is strong. I think they are making money but don't seem to want to share this news with us. But I cannot say this to anyone, certainly not my staff, because I will get in trouble." (Sales manager; tourist agency, Thessaloniki) 